\title{
TRANSCENDING DISCIPLINES: ENGAGING COLLEGE STUDENTS IN INTERDISCIPLINARY RESEARCH, INTEGRATED STEM, AND PARTNERSHIPS
}

\author{
Trina Kilty (D), Andrea Burrows (D), Kate Welsh (D), Kevin Kilty (D), \\ Shawna McBride iD, Philip Bergmaier iD \\ University of Wyoming (United States) \\ tkilty@unyo.edu,aburrow1@unyo.edu,kmuir@umyo.edu,kkilty1@unyo.edu, \\ smcbride@unyo.edu,pbergmai@unyo.edu
}

Received October 2020

Accepted January 2021

\section{Abstract}

An authentic, interdisciplinary, research and problem-based integrated science, technology, engineering, and mathematics (STEM) project may be ideal for encouraging scientific inquiry and developing teamwork among undergraduate students, but it also presents challenges. The authors describe how two interdisciplinary teams $(\mathrm{n}=6)$ of undergraduate college students built integrated STEM projects in a research based internship setting, and then collaboratively brought the project to fruition to include designing lessons and activities shared with $\mathrm{K}-12$ students in a classroom setting. Each three person undergraduate team consisted of two STEM majors and one Education major. The Education majors are a special focus for this study. Interviews, field observations, and lesson plan artifacts collected from the undergraduate college students were analyzed according to authenticity factors, the authentic scientific inquiry instrument, and an integrated STEM instrument. The authors highlight areas of strength and weakness for both teams and explore how preservice teachers contributed to integrated STEM products and lessons. Teacher educators might apply recommendations for teacher preparation and professional development when facilitating authentic scientific inquiry and integrated STEM topics with both STEM and non-STEM educators. Undergraduate college students were challenged to fully integrate the STEM disciplines, transitions between them, and the spaces between them where multiple disciplines existed. By describing the challenges of integrating the spaces between STEM, the authors offer a description of the undergraduate college students' experiences in an effort to expand the common message beyond a flat approach of try this activity because it works, to a more robust message of try this type of engagement and purposefully organize for maximum results.

Keywords - Authentic Scientific Inquiry, Integrated STEM, Undergraduate research, Interdisciplinary research, Partnerships, High-altitude balloon.

\section{To cite this article:}

Kilty, T., Burrows, A., Welsh, K., Kilty, K., McBride, S., \& Bergmaier, P. (2021). Transcending disciplines: Engaging college students in Interdisciplinary Research, Integrated STEM, and Partnerships. Journal of Technology and Science Education, 11(1), 146-166. https://doi.org/10.3926/jotse.1139 


\section{Introduction}

Modern culture in the United States considers science, technology, engineering, and mathematics (STEM) and STEM education important for building a scientifically literate populace to solve urgent $21^{\text {st }}$ Century problems and to develop new strategies and technologies that enrich lives (National Academies of Sciences, 2018). Federal calls to action include supporting transdisciplinary STEM education by "expand[ing] support for STEM learners studying transdisciplinary problems through internships, fellowships..." (National Academies of Sciences, Engineering, \& Medicine, 2018; p. 21). A definition of transdisciplinary, also known as integrated STEM, has certain agreed upon characteristics: a) authentic and complex problems, b) emphasizing similar areas of disciplines in practices, skills, and concepts, and c) implemented by student-centered strategies utilizing collaboration and teamwork (Moore, Johnston \& Glancy, 2020). In the United States, integrated STEM has been written into the three dimensions of the Next Generation Science Standards (NGSS) for K-12 education. One dimension emphasizes cross-cutting concepts that are shared among STEM disciplines, such as patterns or cause and effect (NGSS Lead States, 2013). The other two dimensions are science and engineering practices, which emphasize applications of the connections among the disciplines, and disciplinary core ideas, which emphasize the fundamental concepts necessary to understand each STEM discipline. NGSS has been adopted in many states, and K-12 science teachers are incorporating it into their lessons and activities. Thus, undergraduate college students are increasingly likely to have experienced integrated STEM during their secondary school instruction, even if it was not explicitly explained in that way.

Educators of undergraduate college students may approach integrated STEM in various ways. One way is through non-classroom education using undergraduate research. Although undergraduate college students may encounter opportunities to conduct research in formal coursework leading to a degree in a STEM field, additional opportunities to conduct undergraduate research are available (Burrows, Garofalo, Barbato, Christensen, Grant, Parrish et al., 2017). In this study, six undergraduate college students, composed of two education majors (referred to as preservice teachers in this article), two engineering majors, and two science majors, formed teams in a non-classroom education setting and conducted interdisciplinary research to build a data collection sensor system launched on a high-altitude balloon. The teams translated their project to lesson plans appropriate for a K-12 audience and incorporated the three dimensions of NGSS standards in their planning and teaching of those lessons.

The purpose of this study was to describe how the undergraduate college students' experience incorporated authentic scientific inquiry (ASI) and integrated STEM through their created products. Two undergraduate college student products are the primary focus of this paper: 1) a high-altitude balloon experimental payload and 2) lesson plans with activities suitable for K-12 students. This study focuses specifically on how education majors (preservice teachers) experienced interdisciplinary research with an integrated STEM project to design and build the experimental payload to collect data, and how that experience stretched into delivering lessons and activities to a K-12 classroom. The authors of this study argue that a purposeful team engaged in ASI is necessary for interdisciplinary research to showcase integrated STEM, also known as iSTEM. To this end, the following research questions were pursued: a) How did undergraduate college students describe their interdisciplinary research experience in relation to authentic scientific inquiry and integrated STEM?, and b) How were undergraduate college students' experimental payloads and lesson plans reflective of an authentic scientific inquiry and integrated STEM experience?

\subsection{Conceptual Framework}

A way to engage undergraduate college students with integrated STEM is through authentic learning experiences. Decades ago, Hirst (1974) claimed that artificial separation between how science is taught in the classroom and how science is learned in a real-world setting impedes learning. According to Chin and Malhotra (2002), teachers who encourage authentic activities help eliminate the artificial separation and presumably enhance learning if they take care to move beyond simple inquiry tasks. Activities deemed authentic are described as those that are not simulated or have a real-world component. 
The authors used authenticity in STEM learning in this study as an anchor to frame the context of ASI. Spuck (2014) has described ASI as:

Asking question(s) relevant to real-world issues; using the tools of scientists and engineers; seeking out and evaluating evidence; using that evidence to make a claim; sharing that claim with others in a way that it can be verified, critiqued, and used; and engaging in activities in a constant dialogue with colleagues and within a realworld setting (Spuck, 2014: page 123).

Educational researchers have argued for increasing authentic scientific inquiry activities (Burrows, Wickizer, Meyer \& Borowczak, 2013; Kazempour, 2018; Le, Tingey, Becnel, Giallardon \& Butterfield, 2018; Sabo, Mirisola \& Iguchi, 2014; Strobel, Wang, Weber \& Dyehouse, 2013; Woods, 2012) in STEM education. The authors consider the projects in this study as products of authentic scientific inquiry, because undergraduate college students designed and conducted an experiment that gathered data from sensors attached to an actual high-altitude balloon. The experiment was subject to all of the noise, malfunctions, and failures of an experimental project built from scratch, as well as real-life criteria related to the balloon launch (i.e., weight and space restrictions).

Spuck (2014) developed an instrument to describe how a lesson, activity, or science learning experience exhibits characteristics of ASI. Other researchers have outlined several authenticity factors that help describe aspects of authenticity in a science activity (Strobel et al., 2013). The authors found both the ASI instrument and authenticity factors helpful to understand nuances in authenticity of the products the undergraduate college students created.

The development of integrated STEM stretches back well over a decade. Early on, researchers found that integrated science positively affected motivation, interest, and engagement (Czerniak, 2007). Later, researchers claimed there is "no common understanding or agreement on the nature of STEM education as an integrated or multidisciplinary endeavor" (Roehrig, Moore, Wang \& Park, 2012: page 32). Two years later, however, Moore, Stohlmann, Wang, Tank, Glancy and Roehrig (2014) defined integrated STEM as "an effort to combine some or all of the four disciplines of science, technology, engineering, and mathematics into one class, unit, or lesson that is based on connections between the subjects and real-world problems" (Moore et al., 2014: page 38). Over time, researchers expanded integrated STEM into a conceptual framework (Kelley \& Knowles, 2016). As the topic continued to evolve, researchers recommended that integrated STEM projects elevate engineering aspects beyond just building an actual product to devoting effort to materials used, testing the product, and "optimization of the construction process" (Cuoso \& Simarro, 2020: page 24).

Regarding the integration of engineering specifically, researchers have called for exploration of the interrelationships between engineering and the other STEM disciplines (Custer, Daugherty \& Meyer, 2010; Gattie \& Wicklein, 2007). Integration of STEM may range from little to no integration to full integration of all STEM disciplines, and fully integrated STEM activities are typically authentic (Moore et al., 2020). Burrows and Slater (2015) proposed a framework that would meet the science and engineering practices portion of NGSS by integrating STEM disciplines, and created an instrument to assess what level of integration an activity met. This study expands upon that work by examining how two interdisciplinary teams integrated disciplines of STEM in their projects, both the experimental payload, and lesson plan products.

Undergraduate college students may engage with STEM by conducting research in a non-classroom setting. They may conduct research independently, talk with faculty experts, and communicate among team members. Czerniak (2007) mentioned a relative lack of studies that describe integration of STEM by undergraduate college students, and called for future research to provide a more precise description of the benefits of integrated STEM, explaining "additional research would be useful to verify these benefits and determine whether the results can be used to inform school-based practices" (Czerniak, 2007): page 553). Experiences of integrated STEM practices in non-classroom educational settings (Burrows, Lockwood, Borowczak, Janak \& Barber, 2018) may help to fill that gap as best practices are taken forth and applied to 
school-based settings both at K-12 and post-secondary level (Heflich, Dixon \& Davis, 2001; Herrington \& Kervin, 2007; Labouta, Kenny, Anikovskiy, Reid \& Cramb, 2018). In this study, an authentic project, constrained by collecting data on sensors attached to a high-altitude balloon, helped foster integrated STEM as undergraduate college students were encouraged to approach the problem from different perspectives according to their major area of study.

Interdisciplinary research has long been used to enrich STEM education. In 2004, the Committee on Facilitating Interdisciplinary Research (a section of the Committee on Science, Engineering and Public Policy) explained interdisciplinary research as:

\begin{abstract}
A mode of research by teams or individuals that integrates information, data, techniques, tools, perspectives, concepts, and/ or theories from two or more disciplines or bodies of specialized knowledge to advance fundamental understanding or to solve problems whose solutions are beyond the scope of a single discipline or area of research practice. (page 2)
\end{abstract}

Researchers have explored the benefits of interdisciplinary research, in which those in different disciplines come together to work on a common question in an integrated way, as more satisfying than multidisciplinary research, in which those who work on a common problem leave with largely unchanged perspectives about disciplines outside of their expertise (Borrego \& Newswander, 2008). In the project described in this article, the undergraduate college students' products revealed how they combined and shared their expertise as they developed an experimental payload and lesson plans.

Problem-based learning functioned as a mechanism for using ASI and integrated STEM for undergraduate college students to conduct research in an education setting outside of formal coursework. Woods (2012) stated that authentic problem-based learning "poses a problem that is set before the knowledge has been acquired, and the problem causes the students to acquire the knowledge they need to complete the task" (Woods, 2012: page 136). Moore et al. (2020) associate fully integrated STEM with problem-based learning. Moreover, authentic problem-based learning facilitates constructivist learning, which encourages metacognition and engages learners in a deep manner (Myers \& Nulty, 2009). Components of problem-based learning include a) an ill-structured problem, b) success defined in more ways than just according to engineering standards, c) governed by constraints, d) knowledge is distributed among team members, e) requires extensive collaboration, f) encounter unanticipated problems, where teams must rely on fundamental concepts, and g) teamwork is crucial (Jonassen, Strobel \& Lee, 2006).

Another aspect of interdisciplinary teams involves forming partnerships and teamwork. Researchers have stressed the importance of future engineers "building relationships to the natural, social, and behavioral sciences, mathematics, and computational sciences" (Malcom, 2008: page 37) to thrive in modern society. To accomplish this requires both hard and soft skills (Burrows et al., 2013). Interdisciplinary teams are used often in medical and other fields, and research has shown that effective interdisciplinary team work includes leadership, communication, development, procedures, skill mix, team climate, team work, vision, quality, and understanding (Nancarrow, Booth, Ariss, Smith, Enderby \& Roots, 2013). Interdisciplinary teams may facilitate integrating STEM and indeed researchers have claimed, "solving more realistic, more complex problems requires students to work together; thus integrating STEM is thought to afford opportunities to develop teamwork (Moore et al., 2020: page 6). ASI and integrated STEM provided the conceptual framework for the authors of this study to investigate how undergraduate college students functioned as an interdisciplinary team composed of STEM majors and education major, and, how the team utilized members' content areas of expertise to develop their projects.

The previously described conceptual framework guided the authors to create a grant funded internship program in which undergraduate STEM majors and undergraduate education majors (preservice teachers) collaboratively designed and developed an authentic integrated STEM project. Working as an interdisciplinary team, undergraduate college students selected and explored a scientific question or engineering problem, conducted research to design and build a payload to collect data using a high-altitude balloon flight, and translated the overall project into outreach lessons and activities for K-12 students. 
High-altitude balloons are used in multiple spaces such as in atmospheric science (Lamb, Lees \& Bowman, 2018) and in education (McKaig, Caro, Hyer, Talburt, Verma, Cui et al., 2019). The high-altitude balloon, as a vehicle for data collection, served as the "catalyst for integration" (Czerniak, 2007: page 541). Although balloon projects have been used for scientific research and projects have included secondary and postsecondary students for years (Denny, 2016; Lally, 1982; Larson, Armstrong \& Hiscock, 2009; Saba, Mirisola \& Iguchi, 2005), the projects often collect data to answer pre-determined questions related to temperature and other atmospheric characteristics (Fong, Kennon \& Robers, 2016; Merhar, Capuder, Maroševic, Artac, Mozer \& Štekovic, 2016). The project in this study differs by having undergraduate college students choose their own ill-defined questions and problems.

\section{Design/Methodology/Approach}

This study was conceptualized as describing STEM integration, interdisciplinary research, and authenticity of scientific inquiry, using authentic problem-based learning in an interpretivist theoretical perspective (Koro-Ljungberg, Yendol-Hoppey, Smith \& Hayes, 2009). This study used constructivism within the interpretivist stance to describe individuals' experiences and meaning-making processes and focus on resulting products (Koro-Ljungberg et al., 2009). Participants in this study were sampled purposefully and their descriptions were gained by what they produced, i.e., experimental payload and lesson plans. The role of the authors as researchers were detached through allowing study participants choice of experiment and K-12 classroom lesson design, thus showcasing the study participants as main knowledge producers (Koro-Ljungberg et al., 2009).

The purpose of this study was to examine and describe how undergraduate college students experienced STEM, materialized their created products, incorporated authentic scientific inquiry, and integrated STEM disciplines. Although these ideas are not new and have been explored, the authors determined that the combination of factors posed an interesting area to research. Two teams of undergraduate college students a) decided on a problem to solve or a question to answer, b) developed and built an experimental payload to collect data, c) collected and analyzed data using a high-altitude balloon flight, and d) planned lessons and activities as STEM outreach to K-12 students. The last two steps depended on the undergraduate college students integrating and applying fundamental knowledge of several disciplines of STEM to both explore their own project and then teach it to others.

\subsection{Research Questions}

To explore how authentic problem-based learning supported ASI and iSTEM during the undergraduates' experience, the authors pursued the following research questions:

- How did undergraduate college students describe their interdisciplinary research experience in relation to ASI and iSTEM?

- How were undergraduate college students' experimental payloads and lesson plans reflective of the ASI and iSTEM experience?

\subsection{Method}

The study took place at a university in the United States. As of Fall 2019, approximately 28\% of the entire university student body were part of the College of Arts \& Sciences (which includes science and mathematics majors), 15\% were part of the College of Engineering, and just under 10\% were part of the College of Education (Borwn \& Gold Report, 2019). The state is primarily rural and large in geographic area. The university fosters relationships with K-12 teachers and enjoys support from K-12 teachers for outreach activities. The study utilized qualitative research methodology. The study was bounded by a case, i.e., the undergraduate college students who consented to participate in the project and the research (Merriam \& Tisdell, 2016). The unit of analysis was the cohort of six undergraduate college students who participated in the project (Merriam \& Tisdell, 2016). 
The project took place during two semesters. During the first semester, undergraduate college students formed diverse teams and defined a question or problem to pursue and designed how to collect data using sensors on a high-altitude balloon, or experimental payload. The semester concluded with a test launch of a prototype payload. During the second semester, teams refined the experimental payload. They developed lesson plans to distill their projects to outreach-style learning experiences in K-12 schools and taught one to three pre-launch and one post-launch lessons and activities to a class of K-12 students. The launch itself occurred on-site at the K-12 school. Table 1 describes the characteristics of each team and provides an overall summary of each team's payload and lesson plan.

Purposeful sampling was done initially when accepting undergraduate college students into the project, according to a) sophomore or junior status, b) STEM major or education major (elementary or secondary, any content area), and c) members of traditionally underrepresented groups were encouraged to apply. Institutional (IRB) approval was granted and all six individuals who participated in the project consented to participate in this study. The authors encouraged two diverse teams of three individuals each to form, i.e., each team of three was composed of an education major, an engineering major, and a science major. As it turned out, the science majors in both teams majored in astronomy and astrophysics.

\begin{tabular}{|c|c|c|c|c|c|}
\hline Team Topic & Pseudonym & Gender & Intended Major & Payload & Lesson Plan \\
\hline \multirow{3}{*}{$\begin{array}{l}\text { Cosmic } \\
\text { Radiation }\end{array}$} & Ray & Male & $\begin{array}{l}\text { Mechanical } \\
\text { Engineering }\end{array}$ & $\begin{array}{l}\text { Geiger counter measured } \\
\text { radiation at altitude }\end{array}$ & $\begin{array}{l}\text { Role play to design } \\
\text { shielding }\end{array}$ \\
\hline & Rose & Female & $\begin{array}{l}\text { Astronomy \& } \\
\text { Astrophysics }\end{array}$ & & \\
\hline & Randy & Male & $\begin{array}{l}\text { Secondary Social } \\
\text { Studies Education }\end{array}$ & & \\
\hline \multirow{3}{*}{$\begin{array}{l}\text { Speed of } \\
\text { Sound }\end{array}$} & Seth & Male & $\begin{array}{c}\text { Electrical } \\
\text { Engineering }\end{array}$ & $\begin{array}{l}\text { 3D printed sensor } \\
\text { measured sound at altitude }\end{array}$ & $\begin{array}{c}\text { Investigated equation } \\
\text { for speed of sound }\end{array}$ \\
\hline & Sam & Male & $\begin{array}{l}\text { Astronomy \& } \\
\text { Astrophysics }\end{array}$ & & \\
\hline & Sandy & Female & $\begin{array}{l}\text { Secondary English } \\
\text { Education }\end{array}$ & & \\
\hline
\end{tabular}

Table 1. Undergraduate college student participant characteristics

\subsubsection{Data}

Data gathered included interviews, field notes, and artifacts. Interviews were semi-structured and transcribed. Field notes consisted of observations by the authors during weekly meetings when each team brainstormed, designed, planned, and built the experimental payloads. Field notes were also taken as teams participated in balloon launches, and as teams taught lessons and activities in the classroom to K-12 students. Artifacts included lesson plans and activities, as well as the experimental payload itself. Lesson plans did not follow a specific format. The authors furnished standards to address, such as the Next Generation Science Standards (NGSS), to the undergraduate college students, and encouraged them to incorporate authentic, hands-on activities and avoid lecturing more than ten minutes at a time. The preservice teachers in each group ensured that there was beginning expertise in utilizing standards for curricular development. Because the lesson plans were meant as outreach activities, there were no formal assessments of K-12 learning, and thus K-12 students were not included in the IRB or directly in this study.

\subsubsection{Data Analysis}

Products were analyzed as indicative of the participants' perceptions of the experience. Lessons and activities, supplemented by field notes taken during direct observations at meetings and in the K-12 classroom, were assessed according to the ASI instrument developed by Spuck (2014), according to presence of authenticity factors developed by Stroebel et al. (2013), and according to an exploratory 
iSTEM level assessment instrument developed by Burrows and Slater (2015). Interview transcriptions were analyzed according to components of ASI and iSTEM as either present or not.

The authors ensured trustworthiness and credibility by gathering multiple sources of data, i.e., written lesson plans and activities, field notes of observations during K-12 classroom activities, field notes of meetings and test launches, and interviews with the participants to gain their perspectives. The authors offered the participants a chance to member check the interviews, read the manuscript, and suggest changes. The authors used multiple methods of data analysis: a) the ASI instrument (Spuck, 2014), b) authenticity factors (Strobel et al., 2013), and c) the iSTEM instrument (Burrows \& Slater, 2015) to triangulate data (Merriam \& Tisdell, 2016). Assessing according to three different instruments provided credibility through constant comparison of multiple forms of analysis (Merriam \& Tisdell, 2016). The role of authenticity and the extent of STEM integration, both in developing an experimental payload and in developing lessons and activities delivered to the K-12 students, was discussed among the authors, who reached a consensus. This study claims communicative and pragmatic validity by readers ascertaining if the results apply to their own situation (Koro-Ljungberg et al., 2009). In the following sections, the authors describe that the purposefully organized nature of this study resulted in the undergraduate college students engaging with integrated STEM.

\subsection{Results}

\subsubsection{Field Note and Artifact Evidence}

Overall, both teams integrated STEM interdisciplinary research to collect data from experimental payloads they designed for a high-altitude balloon launch. Both teams successfully taught lessons and activities to $\mathrm{K}-12$ students in a classroom setting. The cosmic radiation team organized high school students into two groups to role-play as competing countries in a space race. Each group built a radiation shield for a Geiger counter using their own design. Each high school student was assigned a role, such as director, engineer, computer scientists, public relations expert, or research and development expert and given instructions about how to fulfill that role. For example, computer scientists learned how to program an Arduino to write the Geiger counter data to a memory card. The payloads were attached side-by-side for the balloon launch and data was analyzed for shielding effectiveness. The speed of sound team concentrated on data interpretation of a 3D-printed measuring device, which recorded to a memory card. Sensors attached to the balloon recorded temperature, humidity, etc. The speed of sound team encouraged middle school students to form small groups to graph speed of sound against one variable and compared the graphs to the accepted equation for the speed of sound.

The authors assessed the payload and lesson products according to the ASI instrument. Table 2 displays the ASI instrument with each team's alignment with those components (Spuck, 2014). For each prompt, the authors considered how each team addressed both the payload (i.e., developing the interdisciplinary research payload as a team of three) and the classroom (i.e., lesson plan design, development, and teaching to a K-12 audience as a team of three) products. Sources of data include field notes of observations of lessons and activities, as well as lesson plans.

The results using the ASI instrument reveal components both teams met ("yes" answers). Both teams used technology to gather actual data gathered by the sensors on the balloon payload to answer their questions (ASI\#3). As Rose pointed out during an interview, "In my opinion there's only so much you can learn through lecture, and you just have to do things, which is why I like, for STEM majors and stuff, [that] there's so many labs." Both teams facilitated small group work and kept lecturing to a minimum. The high-altitude balloon and payload served as a technology catalyst for both teams. Both teams communicated their findings to a larger audience at professional conferences and both teams prepared their lesson plans for publication (ASI\#8, 10). 


\begin{tabular}{|c|c|c|}
\hline Components of ASI & Cosmic Radiation Team & Speed of Sound Team \\
\hline $\begin{array}{l}\text { ASI\#1. Work toward a solution to a real-world } \\
\text { problem, provide the scientific community with } \\
\text { answers to current or new science related } \\
\text { questions, or contribute in a meaningful way to } \\
\text { the body of knowledge the scientific community } \\
\text { has access to? }\end{array}$ & $\begin{array}{l}\text { Yes: Payload } \\
\text { Yes: Classroom }\end{array}$ & $\begin{array}{l}\text { No: Payload-investigated a } \\
\text { known equation that rendered } \\
\text { balloon launch unnecessary } \\
\text { Yes: Classroom }\end{array}$ \\
\hline $\begin{array}{l}\text { ASI\#2. Thoroughly explore and summarize the } \\
\text { current information available on the subject } \\
\text { being studied? }\end{array}$ & $\begin{array}{l}\text { No: Payload } \\
\text { No: Classroom-Did not follow } \\
\text { through in final lesson }\end{array}$ & $\begin{array}{l}\text { No: Payload } \\
\text { No: Classroom-Attempted } \\
\text { with the final activity }\end{array}$ \\
\hline $\begin{array}{l}\text { ASI \#3. Use science instruments and technology } \\
\text { (e.g., rulers, thermometers, computers, digital } \\
\text { cameras, iPhones, data analysis software, } \\
\text { microscopes, telescopes, spectrometers, etc.) to } \\
\text { collect and analyze data? }\end{array}$ & $\begin{array}{l}\text { Yes: Payload } \\
\text { Yes: Classroom }\end{array}$ & $\begin{array}{l}\text { Yes: Payload } \\
\text { Yes: Classroom }\end{array}$ \\
\hline $\begin{array}{l}\text { ASI\#4. Use "grade appropriate" mathematics } \\
\text { (e.g., math functions, graphing, plotting } \\
\text { coordinates on a map, derive equations, etc.) in } \\
\text { the analysis of data? }\end{array}$ & $\begin{array}{l}\text { No: Classroom-Tracked budget, } \\
\text { no analysis } \\
\text { N/A: payload (did not build } \\
\text { payload in K-12 classroom) }\end{array}$ & $\begin{array}{l}\text { Yes: Classroom-Graphing, } \\
\text { derive/explain equation } \\
\text { N/A: payload (did not build } \\
\text { payload in K-12 classroom) }\end{array}$ \\
\hline $\begin{array}{l}\text { ASI\#5. Analyze evidence and use the analysis as } \\
\text { a basis for drawing conclusions? }\end{array}$ & $\begin{array}{l}\text { Yes: Payload-Data yielded } \\
\text { unexpected results } \\
\text { Yes: Classroom-communicated } \\
\text { unexpected results to K-12 } \\
\text { audience }\end{array}$ & $\begin{array}{l}\text { No: Payload } \\
\text { Yes: Classroom-Analysis } \\
\text { aligned with equation }\end{array}$ \\
\hline $\begin{array}{l}\text { ASI\#6. Have the opportunity to develop or } \\
\text { refine the question driving the activity, and to } \\
\text { present new questions that come about as a } \\
\text { result of their work? }\end{array}$ & $\begin{array}{l}\text { No: Only one launch, questions } \\
\text { posed briefly to students in a } \\
\text { remote delivery to elicit data } \\
\text { analysis }\end{array}$ & $\begin{array}{l}\text { No: Payload pre-built, no } \\
\text { suggestions solicited from K- } \\
12 \text { students; however, } \\
\text { reflection occurred }\end{array}$ \\
\hline $\begin{array}{l}\text { ASI\#7. Have the opportunity to develop and/or } \\
\text { refine procedures or methods being used? }\end{array}$ & $\begin{array}{l}\text { No: Only one launch } \\
\text { Yes: payload (test launch) }\end{array}$ & $\begin{array}{l}\text { No: Only one launch } \\
\text { Yes: payload (test launch) }\end{array}$ \\
\hline $\begin{array}{l}\text { ASI\#8. Communicate the methods used and the } \\
\text { results of their work to their peers/colleagues } \\
\text { for review and critique of the work of their } \\
\text { peers/colleagues? }\end{array}$ & $\begin{array}{l}\text { Yes: Conference and publishing } \\
\text { opportunities }\end{array}$ & $\begin{array}{l}\text { Yes: Conference and } \\
\text { publishing opportunities }\end{array}$ \\
\hline $\begin{array}{l}\text { ASI\#9. Collaborate with others in meaningful } \\
\text { ways throughout the process? }\end{array}$ & $\begin{array}{l}\text { Yes: Payload-Built project } \\
\text { together } \\
\text { Yes: Classroom-Team-teaching }\end{array}$ & $\begin{array}{l}\text { No: Payload-team remained in } \\
\text { subject matter confines } \\
\text { No: Classroom }\end{array}$ \\
\hline $\begin{array}{l}\text { ASI\#10. Record the results of their work where } \\
\text { it is accessible to the broader scientific } \\
\text { community? }\end{array}$ & $\begin{array}{l}\text { Yes: Conference and publishing } \\
\text { opportunities for both payload } \\
\text { and teaching }\end{array}$ & $\begin{array}{l}\text { Yes: Conference and } \\
\text { publishing opportunities for } \\
\text { both payload and teaching }\end{array}$ \\
\hline $\begin{array}{l}\text { Totals for each team: each component } \\
\text { counted once for payload; once for } \\
\text { classroom }\end{array}$ & $\begin{array}{l}\text { Cosmic Radiation } \\
\text { Yes }=12 \\
\text { No }=8\end{array}$ & $\begin{array}{l}\text { Speed of Sound } \\
\text { Yes }=9 \\
\text { No }=11\end{array}$ \\
\hline
\end{tabular}

Table 2. Assessment of teams by ASI components

The ASI instrument also revealed areas in which both teams were challenged ("no" answers). Neither group conducted detailed background research to explore possible interpretations of unexpected data collected at high altitude (ASI\#2). Although members of both teams engaged in some final reflection and speculation about optimization, the timeframe of the project did not allow for refinement and re-launch of the payload after the lessons and launch were delivered to K-12 students (ASI\#6, 7). The timeline is partially responsible for the teams not having the opportunity to refine, develop, or present new questions about their work (ASI\#6, 7). The cosmic radiation team did not pivot to prepare lessons suitable to explore unexpected results. The original lesson plan was to deliver a "winner" clearly interpreted from the side-by-side graphical representation of each K-12 student team's shielding effectiveness. Although the original plan did account for analyzing evidence to draw conclusions (ASI\#5), the unexpected results eliminated that plan's feasibility in terms of identifying a "winner." 
Additionally, the two teams differed in four components of ASI. Working toward a solution to a real-world problem, or contributing in a meaningful way to scientific knowledge (ASI\#1), was met by the cosmic radiation team but not the speed of sound team. The speed of sound team did not contribute to scientific knowledge because their scientific question did not need a high-altitude balloon launch. Using grade-appropriate mathematics (ASI\#4) was absent in the cosmic radiation team, but stressed by the speed of sound team. In the area of analyzing evidence (ASI\#5), the cosmic radiation team met this component, while the speed of sound team did not initially realize that their scientific question probed by their experimental payload did not need a high-altitude balloon launch to answer it. Finally, although collaboration with team members in meaningful ways (ASI\#8) was readily apparent in the cosmic radiation team, the speed of sound team missed opportunities to do so.

The cosmic radiation team met more criteria for ASI. They pursued a solution to the problem of shielding astronauts from radiation. The cosmic radiation team's payload design translated directly to the classroom for K-12 students to design a shield using their choice of preselected materials. The team designated one member (engineering major) to provide a tutorial for the students to program an Arduino. Thus, everything the cosmic radiation team did in their test payload was replicated, with the exception of materials to shield the payload, by the K-12 students. The cosmic radiation team was transparent about the unexpected data the balloon flight revealed, presenting a graph of their results to the K-12 students and admitting to surprising results but not venturing to offer a firm explanation (ASI\#5). The cosmic radiation team did not include grade-appropriate mathematics as an integral part of payload design and development, nor did they in the lesson plans (ASI\#4).

The cosmic radiation team displayed strong partnership skills in developing their payload (each member was present at their meetings and contributed) and teaching in the classroom (ASI\#9). Ray described the classroom teamwork as, "The roles were nice. Having an education student and an engineering student and a physics student...because [Randy] could handle the stuff he was familiar with, and we could all handle the stuff we were familiar with." Rose offered a similar perspective, describing teamwork as:

We talked about it a lot as a group, Yeah, cause, like, [Randy] came up with, like, the idea of the space race thing. I think [Ray] came up with the secret mysterious material to have them, like, do some Internet searching to find their secret material.

Randy described the payload and lesson development process:

We really did put a lot of work into it, not just the [lessons], and [Ray], he is a pretty good teacher, I mean he tanght [Rose] and I how to solder, he taught [Rose] this coding thing with the Arduino. So, I mean, it was pretty fantastic. And [Rose] taught us, [Rose] is like the reason that we are teaching about radiation, cosmic radiation, she's the one who presented that in the first place and encouraged us to read more about it.

The speed of sound team met fewer criteria of ASI. They pursued an answer to the question of how the speed of sound varies with altitude. The speed of sound team lacked meaningful collaboration, both during payload development and in conducting classroom activities (ASI\#9). During interviews, each member of the speed of sound team described an experience of playing an individual role and an understanding of their part as a piece of the whole, but they did not speak of the project holistically. One member used a 3D printer to produce a part, while another member did not appear to have knowledge of the design, only the finished payload. Moreover, the preservice teacher indicated she had not played an active role in the development of the payload. Sandy said, "they kicked me out of their meetings."

The speed of sound team encountered a sensor failure at high altitude and thus selected data from their sensor at lower altitude and corresponding higher temperatures. This produced expected results. The speed of sound team was less transparent in that they did not include K-12 students in discussion and interpretation of unexpected results (ASI\#5). On the other hand, the speed of sound team provided a detailed explanation, referring to a NASA website, for how the equation for the speed of sound depended only on temperature. Calculators were provided for each K-12 student and the team encouraged 
mathematical and graphical analysis appropriate for the age group of the K-12 students (ASI\#4). In terms of the experimental payload, however, contribution to the scientific community was all but absent considering the high-altitude balloon flight itself was unnecessary to collect the data. If the speed of sound depends solely upon temperature, then on-ground experiments would have been sufficient, rendering unnecessary the high-altitude balloon payload and the associated launch, tracking, and recovery (ASI\#1). Had the undergraduate college students done more background research, they might have understood that a balloon flight was not necessary before committing to one. Sam spoke of coming to this realization, "a lot of this experiment actually did not require the balloon because theoretically you could create an ultrasonic rangefinder without any of the extra things that we've attached to it. You could probably just dump it in a freezer."

To further unpack the nuances of challenges unique to each team, the authors assessed each project according to authenticity factors. Table 3 displays the assessment of authenticity each group met in the project and in the K-12 classroom setting (Strobel et al., 2013). Similar to the ASI instrument, data was assessed according to payload development and teaching lessons and activities in the K-12 classroom.

\begin{tabular}{|c|c|c|}
\hline Factors & Cosmic Radiation Group & Speed of Sound Group \\
\hline A1. Real-world context & $\begin{array}{l}\text { Yes: Payload } \\
\text { Yes: Classroom }\end{array}$ & $\begin{array}{l}\text { Yes: Payload } \\
\text { No: Classroom-underdeveloped in } \\
\text { lessons }\end{array}$ \\
\hline A2. Complete task environment & $\begin{array}{l}\text { Yes: Payload-built payload } \\
\text { Yes: Classroom-K-12 built also }\end{array}$ & $\begin{array}{l}\text { Yes: Payload } \\
\text { No: Classroom-pre-built payload } \\
\text { shown to K-12 students }\end{array}$ \\
\hline A3. Ill-structured problem & $\begin{array}{l}\text { Yes: Payload } \\
\text { Yes: Classroom }\end{array}$ & $\begin{array}{l}\text { Yes: Payload } \\
\text { No: Classroom-lesson plans tried to } \\
\text { eliminate }\end{array}$ \\
\hline A4. Suspension of disbelief & $\begin{array}{l}\text { Yes: Payload } \\
\text { Yes: Classroom-role play simulation }\end{array}$ & $\begin{array}{l}\text { Yes: Payload } \\
\text { No: Classroom-underdeveloped }\end{array}$ \\
\hline A5. Interaction among learners & $\begin{array}{l}\text { Yes: Payload-each member } \\
\text { contributed } \\
\text { Yes: Classroom-team-teaching } \\
\text { strategies used }\end{array}$ & $\begin{array}{l}\text { No: Payload-members contributed } \\
\text { according to expertise area } \\
\text { Yes: Classroom-small groupwork } \\
\text { emphasized }\end{array}$ \\
\hline $\begin{array}{l}\text { A6. Decision-making in procedural } \\
\text { contexts }\end{array}$ & $\begin{array}{l}\text { Yes: Payload } \\
\text { Yes: Classroom }\end{array}$ & $\begin{array}{l}\text { Yes: Payload } \\
\text { No: Classroom-prebuilt payload } \\
\text { shown in lessons }\end{array}$ \\
\hline A7. Value beyond school & $\begin{array}{l}\text { Yes: Payload } \\
\text { Yes: Classroom }\end{array}$ & $\begin{array}{l}\text { Yes: Payload } \\
\text { Yes: Classroom }\end{array}$ \\
\hline A8. Values objectively defensible & $\begin{array}{l}\text { Yes: Payload } \\
\text { Yes: Classroom }\end{array}$ & $\begin{array}{l}\text { Yes: Payload } \\
\text { Yes: Classroom }\end{array}$ \\
\hline $\begin{array}{l}\text { A9. Provide information from } \\
\text { real-life }\end{array}$ & $\begin{array}{l}\text { Yes: Payload } \\
\text { Yes: Classroom-used actual data for } \\
\text { analysis }\end{array}$ & $\begin{array}{l}\text { Yes: Payload-used actual data for } \\
\text { analysis } \\
\text { Yes: Classroom-used actual data }\end{array}$ \\
\hline $\begin{array}{l}\text { A10. Classroom-professional } \\
\text { community balance }\end{array}$ & $\mathrm{N} / \mathrm{A}$ & $\mathrm{N} / \mathrm{A}$ \\
\hline $\begin{array}{l}\text { A11. Problem transcends borders } \\
\text { defined by discipline }\end{array}$ & $\begin{array}{l}\text { Yes: Payload } \\
\text { Yes: Classroom-added computer } \\
\text { science, engineering technology }\end{array}$ & $\begin{array}{l}\text { No: Payload-members stayed within } \\
\text { discipline boundaries } \\
\text { Yes: Classroom-added math }\end{array}$ \\
\hline $\begin{array}{l}\text { Totals for each team: each } \\
\text { factor counted once for } \\
\text { payload; once for classroom }\end{array}$ & $\begin{array}{l}\text { Cosmic Radiation } \\
\text { Yes }=20 \\
\text { No }=0\end{array}$ & $\begin{array}{l}\text { Speed of Sound } \\
\text { Yes }=13 \\
\text { No }=7\end{array}$ \\
\hline
\end{tabular}

Table 3. Assessment of teams according to authenticity factors

The assessment of each team according to authenticity factors further reveal important nuances in differences between the two teams. Similar to the results of the ASI instruments, both teams shared some 
strengths. Both teams saw value beyond school for the overall project, objectively defended those values during professional conference presentations, and provided K-12 students with data from the actual launch (A7, A8, A9).

The cosmic radiation team, however, scored well ("yes" answers) in all authenticity factors. They used a real-world context of shielding astronauts from radiation as the driving problem for K-12 students to solve (A1). The high school students needed to build their own shielding using furnished materials; moreover, they needed to delegate work according to the roles assumed, thereby creating a complete task environment (A2). The problem was ill-structured; the team did not provide quick answers and even added a "mystery" element that students in research and development roles identified through independent research (A3). Role-play is a suspension of disbelief (A4); students engaged in the roles once they became familiar with them using the worksheets the cosmic radiation team provided. The cosmic radiation team worked together to both build the payload as a prototype and teach in the high school classroom (A5). They asked students playing the director role to summarize and present each country's shielding plan and budget (A6), requiring students in economic advisor roles to make decisions about shielding materials. The space race competitive role play strategy did much to transcend borders defined by discipline and even beyond STEM (A11). As Randy pointed out:

It gave a lot of students who might not have found a lot of engagement in a STEM field, it maybe gave them some engagement in the project and so they put a lot more effort into doing PR things, or artistic things, than the science side of it. And they were still invested on how the payload turned out, which was meaningful.

The speed of sound team scored well ("yes" answers) in 13 of the factors, but did not meet authenticity factors ("no" answers) for seven criteria. They missed opportunities to provide real-world applications to the question of how the speed of sound changes with altitude (A1). Seth's remarks on the K-12 classroom experience provide evidence for the authors' impressions of siloed work. Although he mentioned several real-world applications and relevance of the project to high-altitude aircraft (ASI \#1), those ideas were not incorporated into the lesson plans and were not mentioned in the classroom. That may indicate a lack of meaningful interaction (ASI \#9), which prevented the team from working through all ideas together for translating the project for a K-12 audience. Although Seth was enthusiastic about the application of speed of sound to aircraft, he did not push for the topic to be included in the lessons:

I talked to [Sandy] about it and I left the ball in her court, so I kind determined that she was good at figuring out that, and I was good at figuring how to get the thing to work at the computer, design, and the hardware settings. Yeah, and there was only so much time too, so I think she thought about that. Maybe it was one of those things that she thought, well, I don't know if, how, it's going to fit in there.

The speed of sound team showed their prebuilt payload to K-12 students as a visual aid. They did not involve K-12 students in design or building; thus, the speed of sound team did not translate the experimental payload design and building process to the K-12 class and missed an opportunity to facilitate a complete task environment with the K-12 students (A2). Sandy recognized this missed opportunity, and suggested, "It might've been cool for that group if we had got to explain our Arduino situation a little bit cause I think they would've been interested in that. But I don't think we would've had time to do that." Although the speed of sound team's experimental payload development was an ill-structured problem, the team tried to eliminate this by concentrating on experiment process and terms during the K-12 lessons (A3). The suspension of disbelief was not met (A4). Although the team called the middle school students "junior engineers" on a handout, they did not explain what that title meant or what an aeronautical engineer does, for example.

The interaction among the speed of sound team undergraduate college students was not often inclusive; the two STEM majors built the payload while the preservice teacher designed an activity in which K-12 students built a parabolic reflector (A5). Although the K-12 students actively engaged in building the parabolic reflector, the activity suffered from a lack of articulated connection to the overall project. In the classroom, the STEM majors did not appear to quite know how to explain the purpose of the parabolic reflector, developed by the preservice teacher to address the NGSS concept of waves and relate it to the 
central question. Sam said, "some of the takeaways from that in my opinion are a little superfluous in terms of what we needed them to learn to understand the experiment." It followed that decision-making in procedural contexts was underdeveloped; the experimental payload was presented to K-12 students as a finished product with no mention of the process required to build it (A6). Ultimately, because of the underdeveloped lesson plan and limited teamwork, the project did not transcend specific disciplines (A11).

To further explore how each team drew from several disciplines to complete their project, the authors assessed according to the iSTEM (Burrows \& Slater, 2015). Both teams integrated STEM disciplines into their lessons: computer science and engineering design in the cosmic radiation project and mathematics in the speed of sound project. Integration of multiple STEM disciplines, as well as integration of non-STEM disciplines such as English and social studies, were considered in observations and artifacts. Table 4 displays the instrument developed by Burrows and Slater (2015) that the authors used to gauge iSTEM-level.

\begin{tabular}{|c|c|c|c|c|}
\hline Instruction or materials assessment & $\begin{array}{l}-\mathbf{0 -} \\
\text { No evidence }\end{array}$ & $\begin{array}{l}-1- \\
\text { Implicit } \\
\text { evidence }\end{array}$ & $\begin{array}{l}-2- \\
\text { Some or } \\
\text { inconsistent } \\
\text { evidence }\end{array}$ & $\begin{array}{l}-3- \\
\text { Strong, repeatedly } \\
\text { observed evidence }\end{array}$ \\
\hline $\begin{array}{l}\text { iSTEM\#1. Instruction and/or materials } \\
\text { emphasize computational arithmetic as } \\
\text { frequent part of science instruction }\end{array}$ & $\begin{array}{c}\text { Cosmic } \\
\text { Radiation }=0\end{array}$ & 1 & 2 & Speed of Sound $=3$ \\
\hline $\begin{array}{l}\text { iSTEM\#2. Instruction and/or materials } \\
\text { expose frequently learning to the same } \\
\text { phenomena or principal multiple times in } \\
\text { the same discipline }\end{array}$ & 0 & 1 & 2 & $\begin{array}{c}\text { Cosmic } \\
\text { Radiation }=3 \\
\text { Speed of Sound }=3\end{array}$ \\
\hline $\begin{array}{l}\text { iSTEM\#3. Instruction and/or materials } \\
\text { consistently expose learners to the same } \\
\text { phenomena or principal multiple times } \\
\text { using different disciplines }\end{array}$ & $\begin{array}{l}\text { Speed of } \\
\text { Sound }=0\end{array}$ & 1 & 2 & $\begin{array}{c}\text { Cosmic } \\
\text { Radiation }=3\end{array}$ \\
\hline $\begin{array}{l}\text { iSTEM\#4. Engineering design projects are } \\
\text { frequently employed to deepen students' } \\
\text { understanding of targeted content }\end{array}$ & $\begin{array}{l}\text { Speed of } \\
\text { Sound }=0\end{array}$ & 1 & 2 & $\begin{array}{c}\text { Cosmic } \\
\text { Radiation }=3\end{array}$ \\
\hline $\begin{array}{l}\text { iSTEM\#5. Instruction and/or materials } \\
\text { consistently, frequently, and meaningfully } \\
\text { provide multiple engagements with the same } \\
\text { phenomena or principle using mathematics } \\
\text { AND engineering AND multiple disciplines }\end{array}$ & $\begin{array}{l}\text { Cosmic } \\
\text { Radiation }=0 \\
\text { Speed of } \\
\text { Sound }=0\end{array}$ & 1 & 2 & 3 \\
\hline $\begin{array}{l}\text { TOTALS } \\
\text { (calculated by total points assigned) }=\end{array}$ & $\begin{array}{l}\text { Cosmic } \\
\text { Radiation }=9\end{array}$ & $\begin{array}{l}\text { Speed of } \\
\text { Sound }=6\end{array}$ & & \\
\hline
\end{tabular}

Table 4. An iSTEM-level assessment instrument with team scores

Similar to the ASI and authenticity factor instruments, the teams shared areas of strength and challenges. Both teams scored well by emphasizing the central question or problem multiple times in the same discipline, accomplished by several pre-launch lessons and activities using pedagogical strategies such as presentation, interactive review sessions, small group work, and role-play. Both teams held brief review sessions before beginning the next lesson to encourage recall and reinforcement of learning (iSTEM\#2). Both teams missed opportunities, however, to meaningfully provide multiple engagements with the central question or problem using mathematics AND engineering AND multiple disciplines (iSTEM\#5). Although neither team achieved full integration of STEM, the teams varied how they integrated mathematics, engineering, and other STEM disciplines.

The cosmic radiation project's lesson plans, as observed, did not incorporate mathematics other than simple arithmetic by those playing the roles of the economic advisors to track the budget (iSTEM\#1). Although diverse roles were assigned in the lesson activity, curiously a mathematician was not among 
them, even though the lesson plans and instruction emphasized the central problem using different disciplines. Careful attention was given to including all high school students by offering them a choice of roles, and not all the roles were STEM-related. Moreover, within the STEM-related roles, several different disciplines were represented, e.g., the computer scientists, research and development scientists, and engineers (iSTEM\#3). All the roles functioned to bring the project to fruition. Moreover, the cosmic radiation project used the engineering design process in its entirety by students researching, planning, building, testing, and optimizing their design for future iterations (iSTEM\#4). Additionally, the mission was to solve a problem, i.e., design shielding to protect astronauts from cosmic radiation, which team members agreed was closer to engineering than science. Ray described his personal learning growth in several different disciplines, "I learned a ton about high-altitude balloon launches, from zero knowledge to everything now. I learned a little bit about radiation, little bit about Arduinos." Ray was stretched outside of his major intended field of mechanical engineering by learning how to program Arduinos and to then teach K-12 students how to program them.

The speed of sound team's lesson plans included many computational aspects, such as an explanation, not quite a derivation, of the governing equation used to calculate the speed of sound. K-12 students actually graphed the data to gain a representational interpretation (or model) of the data (iSTEM\#1). K-12 students saw how the equation proved true by graphing the speed of sound against relevant and nonrelevant factors (temperature, humidity, etc.) and noting the relationship. The speed of sound concept was emphasized in all the lesson plans and efforts were made to engage K-12 students with that concept through multiple ways such as building parabolic reflectors and activities designed to gauge prior knowledge (iSTEM\#2). The team did not emphasize, however, how different disciplines could approach the question through different techniques (iSTEM\#3). The group focused their lessons to explore and emulate the work of NASA, but primarily emphasized the contributions of scientists, although they did show a clip from the film Hidden Figures in an attempt to showcase computational contributions from diverse groups of people. Sandy provided a summary of what she felt was helpful and not as helpful in the lessons:

The parabolic reflectors weren't super helpful in understanding the actual speed of sound, but they were belpful in understanding waves and how waves propagate speed of sound. So, kind of in an indirect way they were useful. The different videos that we showed didn't really do a whole lot for the speed of sound either. I don't know. I think that really the technology that was most useful for the speed of sound was their calculators that they used to actually calculate the speed of sound.

The speed of sound group did not integrate engineering into the lessons or activities (iSTEM\#4). The authors based this conclusion on observations of greater use of direct instruction and passing around the prebuilt payload rather than encouraging hands-on exploration by K-12 students and soliciting help in building or refining the payload. Although lesson worksheets called K-12 students "junior engineers", engineering design was not employed. K-12 students did not build the payload, nor did K-12 students engage with it in a tactile manner. The members of the speed of sound team all agreed that their project was closer to science than engineering. Because of the low engineering and multi discipline score, the overall integration score was correspondingly low for the speed of sound team.

\subsubsection{Designing the Experiment and Building the Payload}

In semi-structured interviews with the six undergraduate college students, all indicated satisfaction with the experiment and the data collected. Each indicated they had learned something outside of their chosen major of study. Table 5 describes the experience of each team member, as discussed in interviews regarding the actual experiment. Neither of the two preservice teachers offered ideas to refine future experiments. 


\begin{tabular}{|c|c|c|c|}
\hline $\begin{array}{l}\text { Participants: } \\
\text { cosmic } \\
\text { radiation } \\
\text { team }\end{array}$ & $\begin{array}{l}\text { How did participants describe } \\
\text { their experience conducting } \\
\text { the experiment? }\end{array}$ & $\begin{array}{l}\text { Participants: } \\
\text { speed } \\
\text { of sound } \\
\text { team }\end{array}$ & $\begin{array}{l}\text { How did participants describe } \\
\text { their experience conducting } \\
\text { the experiment? }\end{array}$ \\
\hline $\begin{array}{l}\text { Ray } \\
\text { (mechanical } \\
\text { engineering } \\
\text { major) }\end{array}$ & $\begin{array}{l}\text { Did the experiment meet } \\
\text { expectations? } \\
\text { It did and it didn't. We expected the } \\
\text { levels to rise and they did, but we didn't } \\
\text { expect the unusual behavior after } 15 \text { to } \\
20 \mathrm{~km} \text {. Yes, so the shielding, after a } \\
\text { certain altitude, the payloads with } \\
\text { shields on them were reading more } \\
\text { radiation than the payloads with no } \\
\text { shielding, and that was unusual because } \\
\text { under } 15 \mathrm{~km} \text { it was the opposite, which } \\
\text { is what we expected. } \\
\text { What would you have done } \\
\text { differently? } \\
\text { That phenomena of shielding causing } \\
\text { an increase in radiation, that was } \\
\text { completely new. Yeah, so that changed a } \\
\text { lot. If we had known that going in, or } \\
\text { if we had found it earlier, then we } \\
\text { probably would've changed the project } \\
\text { a little in order to accommodate for it. }\end{array}$ & $\begin{array}{l}\text { Seth } \\
\text { (engineering } \\
\text { major) }\end{array}$ & $\begin{array}{l}\text { Did the experiment meet } \\
\text { expectations? } \\
\text { Roughly 15,000 feet everything just goes } \\
\text { south. Your computer and your } \\
\text { theoretical are a little different but you're } \\
\text { better than theoretical, a little different } \\
\text { on that, um, and why I don't know. I } \\
\text { haven't really looked into that I need to } \\
\text { look into it. I mean to, I just haven't had } \\
\text { time. So this has a lot of other } \\
\text { applications to it too. So, it's absolutely } \\
\text { fascinating stuff. } \\
\text { What would you have done } \\
\text { differently? } \\
\text { We had an ultrasonic distance sensor that } \\
\text { failed the first time, and all of us were } \\
\text { sitting there thinking, what the heck is } \\
\text { going on with this thing. That thing went } \\
\text { up once and it failed. How do you do this } \\
\text { so that it survives these kind of } \\
\text { temperatures?. }\end{array}$ \\
\hline $\begin{array}{l}\text { Rose (physics } \\
\text { major) }\end{array}$ & $\begin{array}{l}\text { Did the experiment meet } \\
\text { expectations? } \\
\text { We got some really good data but we } \\
\text { were expecting there to be, like a } \\
\text { significant or hopefully significant... } \\
\text { significantly less radiation and as you } \\
\text { know we got a little bit more radiation } \\
\text { up in the stratosphere, so that didn't } \\
\text { meet our expectations but earlier on, } \\
\text { lower in the atmosphere, it did, } \\
\text { definitely. } \\
\text { What would you have done } \\
\text { differently? } \\
\text { I think we said that aluminium might } \\
\text { have worked better. Because when we } \\
\text { did the initial test on the ground, } \\
\text { galvanized steel works better obviously } \\
\text { on the ground, because it's a lot thicker. } \\
\text { But I think we said that aluminium } \\
\text { could possibly work better up in the } \\
\text { atmosphere. }\end{array}$ & $\begin{array}{l}\text { Sam (physics } \\
\text { major) }\end{array}$ & $\begin{array}{l}\text { Did the experiment meet } \\
\text { expectations? } \\
\text { I think it met my expectations save for } \\
\text { the fact that our temperature, our } \\
\text { ultrasonic rangefinder, was only rated for } \\
\text { so cold and we didn't realize that until } \\
\text { after we had recorded all of our data and } \\
\text { like, huh, half our data doesn't even look } \\
\text { good! We only have like } 30 \text { minutes of } \\
\text { data because it gets too cold and nothing } \\
\text { works. } \\
\text { What would you have done } \\
\text { differently? } \\
\text { I think an update to this project would be } \\
\text { to find a rangefinder that will work in } \\
\text { those colder temperatures...I mean we } \\
\text { could probably, there might be a way to } \\
\text { circumvent it with a heat pad on the } \\
\text { sensor itself, but I don't know, that seems } \\
\text { a little risky to me, putting hot things next } \\
\text { to electronics that are liable to catch fire. }\end{array}$ \\
\hline $\begin{array}{l}\text { Randy } \\
\text { (secondary } \\
\text { education } \\
\text { major-Social } \\
\text { Studies) }\end{array}$ & $\begin{array}{l}\text { Did the experiment meet } \\
\text { expectations? } \\
\text { The fact that it stayed together and it } \\
\text { collected data, thankfully, but the data } \\
\text { that was collected was unexpected. So, } \\
\text { yeah, I don't think the data collected } \\
\text { went according to plan, but I think it } \\
\text { was perfect, everything went perfect in } \\
\text { the end, the data that we collected was } \\
\text { interesting, just not what we expected. }\end{array}$ & \begin{tabular}{|l|} 
Sandy \\
(secondary \\
education \\
major-English)
\end{tabular} & $\begin{array}{l}\text { Did the experiment meet } \\
\text { expectations? } \\
\text { I didn't really hope for a whole lot, just } \\
\text { for it to measure stuff for the kids to } \\
\text { interact with. I didn't really care what it } \\
\text { got or how long it got stuff, as long as it } \\
\text { got something. }\end{array}$ \\
\hline
\end{tabular}

Table 5. Interview excerpts for each team regarding the experiment

Both teams indicated surprising results that may have been addressed by refining their experimental payload and with subsequent balloon flight testing. The STEM majors offered specific ways to improve 
and refine future experiments. Due to the nature of the single launch with K-12 students to collect data, however, there was no opportunity to develop and/or refine procedures and optimize the experiment, which presented a challenge to both teams in meeting the ASI criteria (ASI \#6, 7). This challenge may have been due to how the project was organized. Time restrictions allowed only one launch with K-12 student participation, thereby eliminating an opportunity to return to the classroom, revise, optimize, and re-launch the payload to compare results. Although undergraduate college students revised their payload and conducted test launches in the semester prior to visiting the K-12 classroom, that trial-and-error process remained behind the scenes and was not shared with K-12 students.

\subsubsection{Preservice Teacher Contributions}

Although neither preservice teacher offered concrete ways to improve the experiment, both had several ideas regarding how the lessons could have been strengthened or ways to improve future lessons. Randy, the secondary social studies preservice teacher, described a broadening appreciation and interest in teaching integrated STEM. He explained that an ASI approach was not something he was used to because as a K-12 student, his classes had been lecture-based, "all the science classes that I remember I had were lecture-heavy, so yeah, not a lot of engagement, stuff like that." He expressed interest during future employment to become involved with interdisciplinary projects, saying, "this program has encouraged me to seek an endorsement in science... it has sparked a whole new interest I didn't know was there."

Randy created a slideshow for the high school students emphasizing a common thread of groundbreaking scientists as all having hands by displaying photos of groundbreaking scientists and then asking students what each of those scientists had in common. The answer he was looking for was that they all have hands, which exemplifies his emerging interest in finding common ground in interdisciplinary integration. His interview responses reveal how the cosmic radiation team transcended borders of their disciplines (A11). His lesson plan, which he indicated was based on one he had done in an earlier education class, emphasized how several disciplines work together to build a product, and therefore showcases a great deal of integrated STEM (A11, iSTEM\#3, 4).

Sandy, the secondary English preservice teacher's interview responses focused on the K-12 classroom experience. She did not indicate much experience with designing the experiment or building the payload, thus implying the team overall lacked interaction among members (A5). Sandy did not integrate her own expertise in English education by incorporating written or verbal communication into the lessons and activities. Sandy developed the parabolic reflector activity and tried to make connections to sound as a wave, an NGSS concept (NGSS Lead States, 2013). Although asking K-12 students to build a parabolic reflector was an interactive hands-on experience, none of the STEM majors in the speed of sound team articulated how the activity integrated with the central question of how the speed of sound is affected by altitude, indicating a disconnect between disciplines and underdeveloped communication among the team (iSTEM\#3).

Sandy was integral in bringing the data interpretation piece to the K-12 classroom. She recognized this as a crucial part of an ASI process and mentioned that calculators were perhaps the "the technology that was most useful" for the K-12 students to gain understanding of the data and make sense of the overall experiment. Sandy's efforts resulted in using technology such as calculators to analyze data (ASI \#3) and using grade appropriate mathematic functions of graphing in the analysis of data (ASI \#4).

\section{Discussion and Conclusion}

\subsection{Team Experiences-Integrated STEM}

Preservice teachers made important contributions to integrating STEM in K-12 lessons and activities through partnerships by transcending disciplines and teamwork. Randy's contribution to the cosmic radiation team in incorporating role-play according to both STEM and non-STEM professions strengthened the overall integration and the authenticity of the project as translated to lessons and activities. Randy delegated roles to the STEM majors as well, guiding them to teach according to expertise 
to small groups. Sandy's contribution to the speed of sound team integrated mathematics, assisted by Sam, who led K-12 students through a detailed explanation of the speed of sound equation, supported by information from a NASA website. The speed of sound team provided a real-world example of how scientific data can support hypotheses and showed students the real-world relevance and application of an otherwise abstract mathematical equation.

The STEM majors of both teams also made valuable contributions regarding content, even though the ideas were not always implemented in the K-12 classrooms. Ray and Rose, in the cosmic radiation team, taught both in and out of their comfort zone to lead tutorials for small groups of high school students. In the speed of sound team, Sam integrated the speed of sound equation into graphical analysis to show middle school student how equations reflect real-life phenomena. Seth had several ideas about applying the speed of sound to high-altitude aircraft and how cold temperatures affect design of technology.

Although all members of each team provided valuable contributions, the cosmic radiation team scored higher in both authenticity factors and integrated STEM. Moreover, the cosmic radiation team showed greater teamwork skills. As the cosmic radiation team worked on their payload, they effectively engaged in problem-solving and taught pertinent parts of their content areas to the other two members of their team, exemplifying Woods' (2012) description of the effectiveness of authentic problem-based learning mechanism. This persisted in the K-12 classroom, where the authors observed the team arranging K-12 students into groups according to content area and teaching pertinent material to those groups. The cosmic radiation team stressed real-world relevance, learner interaction, the importance of multidisciplinary roles contributing to success, and used an ill-structured, procedural approach to data analysis, all of which contributed to an integrated STEM experience as Roehrig et al. have described (2012).

On the other hand, the speed of sound team, who scored lower in authenticity factors and integrated STEM, missed opportunities to develop teamwork skills. This group appeared to silo, each member concentrating on an area of expertise and/or interest, but never quite managing to transcend the borders of their major disciplines. Overall, the authors saw evidence in interviews, field notes, and artifacts that suggests explicit instruction is needed for sustained impact of both the undergraduate student learning (both hard and soft skills) and for K-12 lesson implementation. This supports the original argument the purposeful teams build partnerships that facilitate interdisciplinary work and integrated STEM projects, as well as supporting integration of STEM (Moore et al., 2020).

What the authors found easiest for the undergraduate college students to accomplish in a non-classroom learning environment, without explicit instruction, was communicating results of undergraduate research to a broader community through conferences and publishing opportunities. This was accomplished by alerting the undergraduate college students to those opportunities, providing financial support for them to attend conferences, and providing editorial guidance for them to publish lesson plans. Through conference and publishing experiences, the undergraduate college students seemed confident in their perception that their project held value beyond undergraduate work and those values were defensible, hallmarks of authenticity as other researchers have pointed out (Spuck, 2014; Strobel et al., 2013). Second, both teams added real-world value and real-world objectives to their experimental payload and provided applications to such. Third, by setting the scope of the project to include data gathered by sensors on a high-altitude balloon, the undergraduate college students were able to use technology to collect data (Spuck, 2014). The materials used in building the experimental payload exposed the undergraduate college participants to learning multiple times in the same discipline (Burrows \& Slater, 2015; McGregor, 2017). Undoubtedly, the task authenticity was beneficial in designing and building the experimental payload from scratch (A2, Strobel et al., 2013). Both teams used a complete task environment to build an experimental payload to answer their question or solve their problem.

An important area in which both teams faced challenges was conducting research to learn current information available on the topic (ASI\#2). Other researchers (Roehrig et al., 2012) mentioned this challenge, claiming that undergraduate college students did not conduct independent research to pursue 
questions and share knowledge with team members, which was similar to this study. Content knowledge, or the lack thereof, was not the problem, however. Others have suggested lack of conducting background research was due to preservice teachers getting in over their head or not being motivated by interest in the field (Roehrig et al., 2012). In this study, none of the undergraduate college participants, STEM majors and preservice teachers, conducted any follow-up research. STEM majors took a passive approach toward researching in the future by mentioning they were signed up for courses next semester that they hoped would further their understanding of the unexpected data gathered during the experiment.

\subsection{Implications for Integrated STEM}

By combining ASI and authenticity with integration of STEM disciplines, this study describes a way for undergraduate college students to function as a team to solve problems or answer scientific questions. The challenges lie in how to encourage integration of the "spaces between" S-T-E-M disciplines and transcend established silos. Both teams made crucial integration steps and both teams missed opportunities in other areas.

To support integration of mathematics with STEM, the authors offer several recommendations. To describe the first, the cosmic radiation team carefully planned activities to include roles for the K-12 students who may not be as interested in science. They did not include mathematics as one of their roles in the space race scenario, however, nor did they emphasize the importance of mathematics in space travel. Adding a mathematician role and emphasizing the role of mathematics in space travel could bring the lesson and activity to a higher level of integrated STEM. Mathematics may be incorporated in a variety of aspects including solving transport equations, graphical analysis, or modeling patterns. More simply, mathematical rigor could be strengthened by details about economics, budget, and price fluctuations of raw materials by the economic advisor's role. Additionally, mathematics may be emphasized by an investigation of how a Geiger counter works.

To support undergraduates using ASI, the authors offer a second recommendation that relates to the application of research to a real-world context. All aspects of an experiment, including adding a control group whenever feasible, should be considered. The cosmic radiation team's payload, while innovative by including both competing K-12 student teams' payloads, neglected to include an experiment control, thereby confounding the results and complicating data analysis. Although the cosmic radiation team included an unshielded Geiger counter to measure radiation in an informal test launch, they did not mention this experiment control with high school students, nor did they add another control payload to that launch. This missed opportunity was reflected in their last lesson, which was delivered remotely and lasted less than 30 minutes. The cosmic radiation team revealed during interviews that they had not conducted background research to understand or teach about secondary spray radiation. Adding a control payload would have contributed to discussions with high school students about how to interpret results, and affected the conclusions drawn (or lack thereof). The lack of an experiment control could be addressed by ensuring that future experiment designs include all necessary components.

To support preservice teachers gaining STEM competency, the authors suggest that science teacher educators need to encourage undergraduate college students to conduct background research, perhaps scaffolded by providing copies of STEM research to preservice teachers and facilitating communication such as inviting experts in the field to hold informal question-and-answer sessions and mentoring. It would likewise benefit STEM experts to fully research a topic in order to conduct outreach activities with K-12 students. Doing so would prepare all educators to explore the meaning of unexpected results and answer questions from an interested and engaged K-12 audience.

To support preservice teachers using ASI and integrated STEM, future teams might include a K-12 audience earlier in the process in order to experience the sometimes frustrating but authentic process of developing a scientific product. Given the iterative nature of this process, writing lesson plans that encompass the uncertainty of test launches and trials may prove challenging for preservice teachers. 
Writing integrated STEM lesson plans can be strengthened by incorporating science and engineering standards such as NGSS, but time constraints for additional iterations to optimize tests to solve ill-structured problems may remain a challenge in formal education settings.

Likewise, dealing with an experiment yielding unexpected results is an issue that teachers must recognize and incorporate into their lessons. Although the STEM majors seemed surprised by unexpected results, all of them readily offered suggestions for how to modify future payload experiments. On the other hand, preservice teachers seemed bewildered by unexpected results and seemed satisfied that the experiment yielded sufficient results to present to the K-12 class. Speculation about unexpected experiment results were largely absent by preservice teachers both publicly in the K-12 classroom and privately in the interview. It is important to note that neither preservice teacher planned to teach STEM for a career. Although that represents a limitation of this study, opportunities exist to explore how preservice STEM teachers approach unexpected experiment results in future research.

There are implications for science teacher educators to best approach how to help preservice teachers navigate the spaces between STEM for authentic interdisciplinary research and application. In general, teacher educators should a) identify the purpose of the project and team, b) recruit a diverse team of subject matter experts and teachers, c) provide support around interdisciplinary research, d) provide support for project expectations, and e) provide a framework for project construction and implementation in relation to roles each member of the team should assume as contributing to the overall project. The authors suggest these recommendations foster development of partnership and teamwork skills.

In conclusion, the authors propose that there is value in authentic projects, and value in encouraging integration among interdisciplinary expertise areas. Importantly, education majors/pre-service teachers are a crucial part of an interdisciplinary team. Undergraduate college students can and do teach each other. Undergraduate research experiences provide value for preservice teachers, and this study is innovative in terms of offering that collaborative experience. The research experience of preservice teachers encompassed more than just experience teaching in a K-12 classroom. Preservice teachers perceived benefit in translating what they learned and integrated STEM into lessons and activities for K-12 students. However, the authors found challenges in massaging the spaces between to promote full STEM integration, primarily in how to motivate undergraduate college students to conduct background research to fully summarize current information on the topic. Future research could focus on these interdisciplinary spaces and the opportunities to use them effectively. Full integration of STEM is a complex process and needs explicit support in how undergraduate college students may incorporate all of the meaningful pieces of authentic science inquiry, but by following the suggested recommendations, teacher educators can guide preservice teachers towards more fully engaging with interdisciplinary research and lesson creation.

\section{Declaration of Conflicting Interests}

The authors declared no potential conflicts of interest with respect to the research, authorship, and/or publication of this article.

\section{Funding}

This material is based upon work supported by the National Science Foundation under Grant No. 1821566. Any opinions, findings, and conclusions, or recommendations expressed in this material are those of the authors and do not necessarily reflect the views of the National Science Foundation.

\section{References}

Borrego, M., \& Newswander, L.K. (2008). Characteristics of successful cross-disciplinary engineering education collaborations. Journal of Engineering Education, 97(2), 123-134. 
Brown \& Gold Report (2019). https://brownandgoldreport.uwyo.edu/

Burrows, A.C., Garofalo, J., Barbato, S., Christensen, R., Grant, M., Parrish, J., et al.(2017). Editorial: Integrated STEM and current directions in the STEM community. Contemporary Issues in Technology and Teacher Education, 17(4). Available at: https://citejournal.org/volume-17/issue-4-17/science/editorial-citejournal-science-education-3-0

Burrows, A., Lockwood, M., Borowczak, M., Janak, E., \& Barber, B. (2018). Integrated STEM: Focus on informal education and community collaboration through engineering. Education Sciences, 8(4). https://doi.org/10.3390/edusci8010004

Burrows, A., \& Slater, T. (2015). A proposed integrated STEM framework for contemporary teacher preparation. Teacher Education and Practice, 28(2-3), 318-330.

Burrows, A., Wickizer, G., Meyer, H., \& Borowczak, M. (2013). Enhancing pedagogy with context and partnerships: Science in hand. Problems of Education in the 21st Century, 54, 7-13.

Chinn, C.A., \& Malhotra, B.A. (2002). Epistemologically authentic inquiry in schools: A theoretical framework for evaluating inquiry tasks. Science Education, 86(2), 175-218. https://doi.org/10.1002/sce.10001

Cuoso, D., \& Simarro, C. (2020). STEM education through the epistemological lens: Unveiling the challenge of STEM transdisciplinarity. In Johnson, C.C., Mohr-Schroeder, M.J., Moore, T.J., \& English, L. D. (Eds.), Handbook of research on STEM education (17-28). Routledge. https://doi.org/10.4324/9780429021381-3

Custer, R.L., Daugherty, J.L., \& Meyer, J.P. (2010). Formulating a concept base for secondary level engineering: A review and synthesis. Journal of Technology Education, 22(1). https://doi:10.2106/jte.v22i1.a.1

Czerniak, C.M. (2007). Interdisciplinary science teaching. In Abell, S.K., \& Lederman, N.G. (Eds.), Handbook of research on science education (537-559). Routledge.

Denny, M. (2016). Weather balloon ascent rate. The Physics Teacher, 54, 268. https://doi.org/10.1119/1.4947151

Fong, B.N., Kennon, J.T., \& Robers, E. (2016). Integrating balloonSAT and atmospheric dynamic concepts into the secondary classroom. The Physics Teacher, 54, 264. https://doi.org/10.1119/1.4947150

Gattie, D.K., \& Wicklein, R.C. (2007). Curricular value and instructional needs for infusing engineering design into K-12 technology education. Journal of Technology Education, 19(1).

https://doi:10.21061/jte.v19i1.a.1

Heflich, D.A., Dixon, J.K., \& Davis, K.S. (2001). Taking it to the field: The authentic integration of mathematics and technology in inquiry-based science instruction. Journal of Computers in Mathematics and Science Teaching, 20(1), 99-112.

Herrington, J., \& Kervin, L. (2007). Authentic learning supported by technology: Ten suggestions and cases of integration in classrooms. Educational Media International, 44(3), 219-236. https://doi:10.1080/09523980701491666

Hirst, P.H. (1974). Knowledge and the curriculum: A collection of philosophical papers. Routledge and Kegen Paul.

Jonassen, D., Strobel, J., \& Lee, C.B. (2006). Everyday problem solving in engineering: Lessons for engineering educators. Journal of Engineering Education, 95(2), 139-151. https://doi.org/10.1002/j.21689830.2006.tb00885.x

Kazempour, M. (2018). Elementary preservice teachers' authentic inquiry experiences and reflections: A multicase study. Journal of Science Teacher Education, 29(7), 644-663. 
Kelley, T.R., \& Knowles, J.G. (2016). A conceptual framework for integrated STEM education. InternationalJournal of STEM Education, 3(11). https://doi.org/10.1186/s40594-016-0046-z

Koro-Ljungberg, M., Yendol-Hoppey, D., Smith, J.J., \& Hayes, S.B. (2009). (E)pistemological awareness, instantiation of methods, and uninformed methodological ambiguity in qualitative research projects. Educational Researcher, 38, 687-699. https://doi:10.3102/0013189X09351980

Labouta, H.I., Kenny, N.A., Anikovskiy, M., Reid, L., \& Cramb, D.T. (2018). Learning science by doing science: An authentic science process-learning model in postsecondary education. International Journal of Science Education, 49(12), 1476-1492. https://doi:10.1080/09500693.2018.1484966

Lally, V.C. (1982). Balloons for science. The Physics Teacher, 20(438). https://doi.org/10.1119/1.2341108

Lamb, O.D., Lees, J.M., \& Bowman, D.C. (2018). Detecting lightning infrasound using a high-altitude balloon. Geophysical Research Letters, 45, 7176-7183. https://doi.org/10.1029/2018GL078401

Larson, S.L., Armstrong, J.C., \& Hiscock, W.A. (2009). The first frontier: High altitude ballooning as a platform for student research experiences in science and engineering. American Journal of Physics, 77, 489. https://doi.org/10.1119/1.3097775

Le, K., Tingey, K., Becnel, T., Giallardon, P., \& Butterfield, T. (2018). Building air quality sensors \& inspiring citizen scientists. Chemical Engineering Education, 52(3), 193-201.

Malcom, S.M. (2008). The human face of engineering. Journal of Engineering Education, 97(3), 237-239. https://doi.org/10.1002/j.2168-9830.2008.tb00974.x

McGregor, S.L. (2017). Transdisciplinary pedagogy in higher education: Transdisciplinary learning, learning cycles and habits of minds. In Transdisciplinary bigher education (pp. 3-16). Springer, Cham.

McKaig, J., Caro, T., Hyer, A., Talburt, E., Verma, S., Cui, K., et al. (2019). A high-altitude balloon platform for space life sciences education. Gravitational and Space Research, 7(1), 62-69.

https://doi.org/10.2478/gsr-2019-0007

Merhar, V.K., Capuder, R., Maroševic, T., Artac, S., Mozer, A., \& Štekovic, M. (2016). Vic goes to near space. The Physics Teacher, 54(482). https://doi.org/10.1119/1.4965270

Merriam, S.B., \& Tisdell, E.J. (2016). Qualitative research: A guide to design and implementation (4th ed.). JosseyBass.

Moore, T.J., Johnston, A.C., \& Glancy, A.W. (2020). STEM integration: A synthesis of conceptual frameworks and definitions. In Johnson, C.C., Mohr-Schroeder, M.J., Moore, T.J., \& English, L.D. (Eds.), Handbook of research on STEM education (3-16). Routledge. https://doi.org/10.4324/9780429021381-2

Moore, T., Stohlmann, M., Wang, H., Tank, K., Glancy, A., \& Roehrig, G. (2014). Implementation and integration of engineering in K-12 STEM education. In Purzer, S., Strobel, J., \& Cardella, M. (Eds.), Engineering in pre-college settings: Synthesizing research, policy, and practices (35-60). Purdue University Press. https://doi.org/10.2307/j.ctt6wq7bh.7

Myers, N.M., \& Nulty, D.D. (2009). How to use (five) curriculum design principles to align authentic learning environments, assessments, students' approaches to thinking and learning outcomes. Assessment and Evaluation in Higher Education, 34(5), 565-577. https://doi:10.1080/02602930802226502

Nancarrow, S.A., Booth, A., Ariss, S., Smith, T., Enderby, P., \& Roots, A. (2013). Ten principles of good interdisciplinary team work. Human Resources for Health 11, 19. https://doi.org/10.1186/1478-4491-11-19

National Academies of Sciences, Engineering, and Medicine (2018). Graduate STEM Education for the 21.t century. The National Academies Press. https://doi.org/10.17226/25038 
NGSS Lead States (2013). Next generation science standards: For states, by states. The National Academies Press.

Roehrig, G.H., Moore, T.J., Wang, H.-H., \& Park, M.S. (2012). Is adding the E enough? Investigating the impact of K-12 engineering standards on the implementation of STEM integration. School Science and Mathematics, 112(1), 31-44. https://doi.org/10.1111/j.1949-8594.2011.00112.x

Saba, M.M.F., Mirisola, L.G.B., \& Iguchi, M. (2005). A low-cost sounding balloon experiment. The Physics Teacher, 43(578). https://doi.org/10.1119/1.2136453

Sabo, C., Burrows, A., \& Childers, L. (2014). Shaking up pre-calculus: Incorporating engineering into K-12 curricula. Advances in Engineering Education, 4(2), n2.

Spuck, T. (2014). Putting the "authenticity" in science learning. In Spuck, T., Jenkins, L., \& Dou, R. (Eds.), Einstein fellows: Best practices in STEM education (118-156). Peter Lang. https://doi.org/10.3726/978-1-4539$1258-4$

Stroebel, J., Wang, J., Weber, N.R., \& Dyehouse, M. (2013). The role of authenticity in design-based learning environments: The case of engineering education. Computers \& Education, 64, 143-152. https://doi:10.1016/compedu.2012.11.026

Woods, D.R. (2012). PBL: An evaluation of the effectiveness of authentic problem-based learning (aPBL). Journal of Chemical Engineering Education, 46(2), 135-144.

Published by OmniaScience (www.omniascience.com)

Journal of Technology and Science Education, 2021 (www.jotse.org)

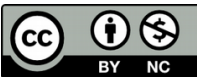

Article's contents are provided on an Attribution-Non Commercial 4.0 Creative commons International License. Readers are allowed to copy, distribute and communicate article's contents, provided the author's and JOTSE journal's names are included. It must not be used for commercial purposes. To see the complete licence contents, please visit https://creativecommons.org/licenses/by-nc/4.0/. 